\title{
HUBUNGAN ANTARA KONSUMSI JUNK FOOD, AKTIVITAS FISIK DENGAN STATUS GIZI SISWA SMA NEGERI 1 JAMBI
}

\author{
Relationship Between Junk Food Consumption, Physical Activity with \\ Nutritional Status of Students SMA Negeri 1 Jambi
}

\author{
M. Dody $\operatorname{Izhar}^{1}$, Ruwayda $^{2}$ \\ ${ }^{1}$ Program Studi Ilmu Kesehatan Masyarakat, FKM Universitas Jambi \\ (E-mail: mdodyizhar@yahoo.com) \\ ${ }^{2}$ Dosen Jurusan Kebidanan Politeknik Kesehatan Jambi Kementerian Kesehatan RI \\ (E-mail: ida_dodyrz@yahoo.co.id)
}

\begin{abstract}
ABSTRAK
Junk food mengandung sebagian lemak yang terakumulasi dalam tubuh. Aktivitas fisik yang rendah dan disertai dengan pola makan yang berlebih dapat menimbulkan obesitas. Penelitian ini merupakan penelitian observasional dengan rancangan cross sectional. Responden penelitian ini adalah siswa kelas XI di SMA Negeri 1 Jambi sebanyak 75 siswa kelas XI diambil secara proportionate stratified random sampling. Keseluruhan analisis menggunakan software analisis statistik dengan tingkat kemaknaan uji $p<0,05$. Hasil penelitian diketahui bahwa status gizi lebih pada anak sebanyak 37 siswa (49,3\%), kebiasaan sering konsumsi junk food sebanyak 45 orang (60\%) dan aktivitas fisik sedang sebanyak 45 orang $(60 \%)$. Ada hubungan secara signifikan kebiasaan konsumsi junk food $(\mathrm{p}=0,001)$ dan aktivitas fisik $(\mathrm{p}=0,000)$ dengan status gizi pada siswa SMA Kelas XI. Penelitian ini menyimpulkan bahwa kebiasaan sering konsumsi junk food dan aktivitas fisik sedang berhubungan secara signifikan terhadap status gizi pada siswa kelas XI SMA Negeri 1 Jambi.
\end{abstract}

Kata kunci: Junk food, aktivitas, status gizi

\section{ABSTRACT}

Junk food contains some of the fat that accumulates in the body. Low physical activity and accompanied by a pattern of excessive eating can lead to obesity. The study was an observational study with cross sectional design. Respondents were students of class XI SMAN 1 Jambi by 75 students of class XI taken by proportionate stratified random sampling. Overall analysis using statistical analysis software to test significance level of $p<0.05$. The survey results revealed that the nutritional status of children as many as 37 students (49.3\%), the habit of frequent consumption of junk food as much as 45 people (60\%) and physical activity were as many as 45 people (60\%). There was a significant relationship habit of junk food consumption $(p=0,001)$ and physical activity $(p=0,000)$ with the nutritional status of high school students Class XI. The study concluded that frequent consumption of junk food habits and physical activity were significantly related to nutritional status in class XI student of SMAN 1 Jambi.

Keywords: Junk food, activity, nutritional status 


\section{PENDAHULUAN}

Gaya hidup modern cenderung menyebabkan status gizi anak di atas normal, sehingga anak menjadi gemuk atau obesitas. Hal ini disebabkan anak banyak makan, tetapi kurang beraktivitas sehingga energi yang masuk ke dalam tubuh jauh lebih banyak daripada energi yang digunakan untuk aktivitas dan pertumbuhan. $^{1}$

Berdasarkan hasil Riset Kesehatan Dasar tahun 2013, prevalensi gemuk dan obesitas secara nasional pada anak umur 16-18 tahun masih tinggi, yaitu 7,3\% yang terdiri dari $5,7 \%$ gemuk dan $1,6 \%$ obesitas. Prevalensi gemuk terendah di Sulawesi Barat $(0,6 \%)$ dan tertinggi DKI Jakarta $(4,2 \%)$. Sementara prevalensi kurang aktivitas fisik pada penduduk umur $>10$ tahun secara umum adalah $26,1 \%$. $^{2}$

Peningkatan jumlah obesitas pada anak saat ini terjadi karena lebih sering mengonsumsi fast food modern yang dapat dikategorikan junk food, yang lebih banyak mengandung energi dan sedikit serat. ${ }^{3} \mathrm{Hal}$ tersebut perlu mendapat perhatian, sebab gizi lebih yang muncul pada usia remaja cenderung berlanjut hingga dewasa dan lansia. Sementara gizi lebih itu sendiri merupakan salah satu faktor risiko penyakit degeneratif. ${ }^{4}$

Junk food dideskripsikan sebagai makanan yang tidak sehat atau memiliki kandungan gizi yang tidak seimbang. Junk food umumnya banyak mengandung gula, tepung, lemak trans, lemak jenuh, garam serta zat pengawet atau pewarna, tetapi sedikit mengandung vitamin dan serat. Makanan dari restoran cepat saji, seperti humberger, ayam goreng dan kentang goreng sering dianggap sebagai junk food. ${ }^{5}$

Efek makanan cepat saji terhadap tubuh yakni dapat memengaruhi tingkat energi tubuh. Junk food mengandung sejumlah besar lemak, dan sebagian terakumulasi dalam tubuh serta berkontribusi terhadap obesitas. ${ }^{6}$ Tingginya Indeks Massa Tubuh (IMT/U) yang menggambarkan gizi lebih diantaranya adalah pola konsumsi tinggi energi dan kurangnya aktivitas fisik yang mengarah pada pola hidup sedentaris (sedentary lifestyle). ${ }^{4}$

Aktivitas fisik merupakan bentuk perilaku sedangkan pengeluaran energi merupakan outcome dari perilaku tersebut. Aktivitas fisik yang rendah disertai dengan pola makan yang berlebih dapat menimbulkan kejadian gizi lebih. Terjadinya peningkatan sel lemak dalam rongga perut atau panggul diakibatkan oleh penimbunan energi dalam bentuk jaringan lemak karena mobilisasi energi menurun. ${ }^{7}$

Berdasarkan beberapa hal tersebut, maka peneliti berasumsi bahwa faktor pola makan kurang baik dan aktivitas fisik ringan diperkirakan sebagai penyebab terjadinya obesitas. ${ }^{8}$ Penelitian ini bertujuan mengetahui hubungan konsumsi junk food dan aktivitas fisik dengan status gizi siswa SMA Negeri 1 Jambi.

\section{BAHAN DAN METODE}

Jenis penelitian yang digunakan adalah observasional dengan rancangan cross sectional. ${ }^{9}$ Penelitian ini dilakukan di SMA Negeri 1 Kota Jambi pada bulan JuliAgustus 2016. Populasi dalam penelitian ini adalah seluruh siswa kelas XI SMA Negeri 1 Kota Jambi berjumlah 343 siswa. Besar sampel minimal sebanyak 75 siswa. Pengambilan sampel menggunakan metode proportionate stratified random sampling. ${ }^{10}$

Data dikumpulkan melalui wawancara dan penimbangan, timbangan injak dan pengukuran tinggi badan (microtoice), data konsumsi junk food dilakukan dengan wawancara langsung pada responden dengan food frequency quesioner. Aktivitas fisik menggunakan Global Activity Questionere (GPAQ) dengan cara menjumlahkan lama waktu dalam melakukan aktivitas perhari dalam minggu dikalikan dengan nilai MET's dari masing-masing aktivitas. Data diolah dengan menggunakan perangkat komputer dan dianalisis secara deskriptif dan analitik. 
HASIL

Berdasarkan hasil penelitian diketahui bahwa karakteristik responden yang berumur 15 tahun sebanyak 60 responden $(80 \%)$ dan yang berumur 16 tahun sebanyak 25 responden (20\%), sedangkan jenis kelamin perempuan sebanyak 45 responden $(60 \%)$ dan sebanyak 30 responden berjenis kelamin laki-laki (40\%).

Tabel 1. Karakteristik Responden

\begin{tabular}{ccc}
\hline Karakteristik & $\mathbf{n}=\mathbf{7 5}$ & $\%$ \\
\hline Umur (tahun) & 60 & 80 \\
15 & 15 & 20 \\
16 & & \\
Jenis Kelamin & 45 & 60 \\
Laki-1aki & 30 & 40 \\
Perempuan & & \\
\hline
\end{tabular}

Hasil analisis univariat menunjukkan bahwa dari 75 responden terdapat sebanyak 45 orang $(60 \%)$ sering mengonsumsi junk food dan sebanyak 30 orang (40\%) jarang mengonsumsi junk food. Sebanyak 45 orang (60\%) memiliki tingkat aktivitas fisik sedang dan sebanyak 30 orang $(40 \%)$ memiliki tingkat aktivitas fisik yang berat. Terdapat 37 orang $(49,3 \%)$ mengalami gizi lebih dan sebanyak 38 orang $(50,7 \%)$ gizi baik.

Berdasarkan analisis bivariat diketahui bahwa kebiasaan konsumsi junk food dan aktivitas fisik secara signifikan berhubungan dengan status gizi siswa Kelas XI SMA Negeri 1 Kota Jambi (Tabel 2).

Tabel 2. Hubungan Kebiasaan Konsumsi Junk Food dan Aktifitas Fisik dengan Status Gizi Siswa Kelas XI SMA Negeri 1 Kota Jambi

\begin{tabular}{|c|c|c|c|c|c|c|c|}
\hline \multirow{3}{*}{ Variabel } & \multicolumn{4}{|c|}{ Status Gizi } & \multirow{2}{*}{\multicolumn{2}{|c|}{ Total }} & \multirow{3}{*}{$p$} \\
\hline & \multicolumn{2}{|c|}{ Gizi Lebih } & \multicolumn{2}{|c|}{ Gizi Baik } & & & \\
\hline & n & $\%$ & $\mathrm{n}$ & $\%$ & $\mathrm{n}$ & $\%$ & \\
\hline \multicolumn{8}{|c|}{ Konsumsi Junk Food } \\
\hline Sering & 29 & 64,4 & 16 & 35,6 & 45 & 100 & \multirow{2}{*}{0,001} \\
\hline Jarang & 8 & 26,7 & 22 & 73,3 & 30 & 100 & \\
\hline \multicolumn{8}{|l|}{ Aktifitas Fisik } \\
\hline Sedang & 31 & 68,9 & 14 & 31,1 & 45 & 100 & \multirow{2}{*}{0,000} \\
\hline Berat & 6 & 20 & 24 & 80 & 30 & 100 & \\
\hline
\end{tabular}

Hasil analisis bivariat, dari 45 responden dengan kebiasaan sering mengonsumsi junk food sebanyak 29 responden $(64,4 \%)$ mengalami gizi lebih dan 16 responden $(35,6 \%)$ mengalami gizi baik. Dari 30 responden yang memiliki kebiasaan jarang mengonsumsi junk food sebanyak 8 responden $(26,7 \%)$ mengalami gizi lebih dan 22 responden $(73,3 \%)$ mengalami gizi baik. Hasil analisis diketahui $p=0,001 \quad(p<0,05)$, yang berarti ada hubungan yang signifikan antara kebiasaan konsumsi junk food dengan kejadian gizi lebih. Dari hasil analisis data dari 45 responden dengan aktivitas fisik sedang sebanyak 31 responden $(68,9 \%)$ yang mengalami gizi lebih dan 14 responden $(31,1 \%)$ yang mengalami gizi baik. Dari 30 responden yang memiliki aktivitas fisik berat sebanyak 6 responden (20\%) yang mengalami gizi lebih dan 24 responden $(80 \%)$ yang mengalami gizi baik. Hasil analisis diketahui $\mathrm{p}=0,000$ $(\mathrm{p}<0,05)$, yang berarti mempunyai hubungan yang signifikan antara aktivitas fisik dengan kejadian gizi lebih.

\section{PEMBAHASAN}

Hasil penelitian menunjukkan bahwa ada hubungan yang signifikan antara konsumsi junk food terhadap kejadian gizi lebih. Sebagian besar yang mengalami gizi lebih, yaitu responden yang memiliki frekuensi makan junk food hingga >4 kali/minggu, jenis junk food yang paling sering dikonsumsi adalah jenis makanan fried chicken, snack dan minuman ringan.

Junk food yang diartikan di sini merupakan junk food yang tergolong sebagai pengganti makanan pokok, seperti Fried chicken, California Fried Chicken (CFC), Pizza, Humberger, Cake keju, Sandwich, fast food, mie, kentang goreng, dan goreng-gorengan. Junk food yang tergolong sebagai jajanan, yaitu Milk shake, permen, minuman bersoda, minuman ringan, keripik asin atau snack, dan es krim. ${ }^{11}$

Penelitian ini sejalan dengan penelitian yang dilakukan oleh Oktaviani 
yang menunjukkan bahwa dari 80 responden yang memiliki Indeks Masa Tubuh (IMT) tinggi sebanyak 43,75\% memiliki kebiasaan konsumsi fast food yang tergolong junk food dengan frekuensi $>7 \mathrm{kali} / \mathrm{ming} g \mathrm{u}$ hasil uji statistik $(\mathrm{p}<0,05) .{ }^{4}$ Hasil ini juga sejalan dengan penelitian Amalia bahwa terdapat hubungan yang bermakna antara frekuensi konsumsi junk food dengan kejadian gizi lebih. ${ }^{12}$ Hasil penelitian Ashlesha menemukan bahwa siswa sekolah dasar yang mengonsumsi fast food/junk food >3 kali/minggu mempunyai risiko 3,28 kali lebih besar menjadi gizi lebih dibandingkan dengan yang jarang 1-2 kali/minggu, frekuensi remaja yang tinggi mengonsumsi junk food dapat meningkatkan timbunan kalori dalam tubuh yang menyebabkan peningkatan nilai IMT (gizi lebih). ${ }^{13}$

Menurut Almatsier, kebiasaan makan remaja dipengaruhi oleh beberapa faktor, yaitu: iklan, kemudahan memperoleh makan siap santap, ${ }^{14}$ sedangkan menurut Sulistyoningsih yang memengaruhi kebiasan makan, yaitu faktor ekonomi, faktor sosio budaya, pendidikan dan lingkungan. ${ }^{15}$ Junk food dipandang negatif karena kandungan gizi didalamnya yang tidak seimbang, yaitu mengandung gula, tepung, lemak trans, lemak jenuh, garam, serta zat pengawet atau pewarna, tetapi sedikit mengandung vitamin dan serat, jika makanan ini sering dikonsumsi secara terus menerus dan berlebihan dikhawatirkan akan berakibat pada terjadinya gizi lebih. ${ }^{16}$

Hasil penelitian pada aktivitas fisik diketahui bahwa ada hubungan yang signifikan antara aktivitas fisik terhaap kejadian gizi lebih. Aktivitas fisik merupakan salah satu faktor yang dapat meningkatkan kebutuhan energi (energy expenditure), sehingga apabila aktivitas fisik rendah maka kemungkinan terjadinya obesitas akan meningkat. Berbagai penelitian menunjukkan bahwa lamanya kebiasaan menonton televisi (inaktivitas) berhubungan dengan peningkatan prevalensi obesitas. Aktivitas fisik yang sedang hingga tinggi akan mengurangi kemungkinan terjadinya obesitas. ${ }^{17}$

Hasil penelitian ini menunjukkan bahwa beberapa siswa memiliki aktivitas berat seperti berolahraga dan hampir sebagian besar melakukan aktivitas sedang yang hanya mengerjakan beberapa pekerjaan di rumah (menyapu, mencuci piring, bersantai, menonton televisi), dengan demikian kurangnya aktivitas memperbesar risiko terhadap peningkatan status gizi pada kelompok remaja dan meningkatkan kejadian obesitas.

Penelitian ini sejalan dengan penelitian sebelumnya yang dilakukan oleh Aini, dari hasil penelitian diketahui bahwa dari hasil uji statistik chi-square didapatkan $(\mathrm{p}<0,05)$ hubungan aktivitas fisik dengan kejadian gizi lebih pada remaja perkotaan (SMA Kesatrian 2 Semarang) yang memiliki persentase tertinggi adalah responden dengan tingkat aktivitas fisik sedang-berat, yakni sebanyak 16 siswa $(53 \%)$, 12 siswa (40\%) diantaranya mengalami gizi lebih dan 4 siswa (13\%) tidak mengalami gizi lebih. ${ }^{18}$

Aktivitas fisik atau perilaku sedentari adalah pergerakan tubuh yang minimal sehingga kebutuhan energi juga minimal. Aktivitas tersebut merupakan contoh perilaku pasif, seperti menonton televisi, membaca, bekerja dengan komputer, menelpon dan sebagainya. Aktivitas tersebut bertendensi meningkatkan berat badan. Aktivitas fisik hanya memengaruhi $30 \%$ pengeluaran energi pada orang berat badan normal, tetapi menjadi sangat penting pada orang dengan obesitas. Selain sangat penting dalam membakar kalori, olah raga juga berperan dalam pengaturan metabolisme normal. ${ }^{19}$

\section{KESIMPULAN DAN SARAN}

Penelitian ini menyimpulkan bahwa kebiasaan konsumsi junk food dan kebiasaan aktivitas fisik berhubungan dengan status gizi pada siswa Kelas XI di SMA Negeri 1 Kota Jambi. Disarankan bagi siswa SMA Negeri 1 Kota Jambi 
untuk lebih memperhatikan makanan yang akan dikonsumsi seperti makanan yang memiliki kandungan gizi seimbang dan beragam, memilih makanan dan jenis jajanan yang menyehatkan bagi tubuh. Selalu melakukan aktivitas fisik rutin untuk membakar kalori serta timbunan lemak dalam tubuh seperti berolahraga minimal 30 menit sehari agar mendapatkan dan mempertahankan berat badan yang ideal.

\section{DAFTAR PUSTAKA}

1. Devi, N. 2012. Gizi Anak Sekolah. PT Kompas Media Nusantara. Jakarta.

2. Riset Kesehatan Dasar (RISKESDAS) 2013. Badan Penelitian dan Pengembangan Kesehatan Kementerian Kesehatan RI. Jakarta.

3. Allo, B., dkk. 2012. Hubungan Antara Pengetahuan dan Kebiasaan Konsumsi Fast food dengan Kejadian Gizi Lebih pada Siswa Sekolah Dasar Negeri Sidirman I Makasar. Skripsi. Makasar : Program Studi Ilmu Gizi FKMUNHAS.

4. Oktaviani, W.D. 2012. Hubungan Kebiasaan Konsumsi Fast Food, Aktivitas Fisik, Pola Konsumsi, Karakteristik Remaja, dan Orang Tua dengan Indeks Massa Tubuh (IMT) (Studi Kasus pada Siswa SMA Negeri 9 Semarang Tahun 2012). Tesis. Semarang : FKM-UNDIP.

5. Persagi. 2009. Kamus Gizi Pelengkap Kesehatan Keluarga. Jakarta; Buku Kompas.

6. Damopolii., dkk. 2013. Hubungan Konsumsi Fast Food dengan Kejadian Obesitas pada Anak SD di Kota Manado. Skripsi. Manado : Program Studi Keperawatan Fakultas Kedokteran Universitas Sam Ratulangi.

7. Gibney., et.al. 2009. Ilmu Kesehatan Masyarakat. Diterjemahkan oleh Andry Hartono. Jakarta : Penerbit Buku Kedokteran EGC. Jakarta.

8. Nadimin., Ayumar \& Fajarwati. 2015. Obesitas pada Orang Dewasa Anggota Keluarga Miskin di Kecamatan
Lembang Kabupaten Pinrang. Media Kesehatan Masyarakat Indonesia. 11(3).

9. Gordis, L. 2000. Epidemiology. WB Saunders Company. Philadelphia, PA.

10. Lemeshow, S., Hosmer, D.W.Jr., Klar, J. \& Lwanga, S.K. 1990. Adequacy of Sample Size in Health Studies. Edisi Bahasa Indonesia. Gadjah Mada University Press. Yogyakarta.

11. Mhaske, S. 2013. Bye Bye Junk Food. International Journal of Food. Nutrition and Dietetics, 1(2).

12. Amalia, R.N., Sulastri, D \& Semiarty, R. 2016. Hubungan Konsumsi Junk Food dengan Status Gizi Lebih pada Siswa SD Pertiwi 2 Padang. Jurnal Kesehatan Andalas, 5(1):185-190.

13. Ashlesha, D \& Nancy, N. 2012. Junk Food in Schools and Childhood Obesity. J. Policy Anal Manage. 31(2): 312-37.

14. Almatsier, S., dkk. 2009. Gizi Seimbang Daur Kehidupan. Jakarta : PT Gramedia Pustaka Utama. Jakarta.

15. Sulistyoningsih, H. 2011. Gizi untuk Kesehatan Ibu dan Anak. Yogyakarta ; Graha Ilmu.

16. Darvisshi, L., Reza, G., Maryam, A., Elnaz, A., Gholamreza, A., Afshin S. 2013. Relationship Between Junk Food Intake and Weight in 6-7 Years Old Children, Shahin Shalir \& Meymeh, Iran. Journal of Education and Health Promotion, 2: 2.

17. Soegih, R.R., dkk. 2009. Obesitas Permasalahan dan Terapi Praktis. Jakarta : Sagung Seto. Jakarta.

18. Aini, S.N. 2013. Faktor yang Berhubungan dengan Kejadian Gizi Lebih pada Remaja di Perkotaan. Unnes Journal of Public Health, 2(1).

19. Salam, A. 2010. Faktor Risiko Kejadian Obesitas pada Remaja. Media Kesehatan Masyarakat Indonesia, 6(3): 185-190. 